\title{
Densely functionalised spirocyclic oxetane-piperidine scaffolds for drug discovery
}

Gemma C. Geary, ${ }^{\text {a }}$ Andrew Nortcliffe, ${ }^{a}$ Christopher A. Pearce, ${ }^{\text {b }}$ Daniel Hamza, ${ }^{\mathrm{b}}$ Geraint Jones, ${ }^{\mathrm{b}}$ and Christopher J. Moody*a

a. School of Chemistry, University of Nottingham, University Park, Nottingham NG7 2RD, UK, c.j.moody@nottingham.ac.uk

b. Sygnature Discovery Ltd, BioCity, Pennyfoot Street, Nottingham NG1 1GF, UK

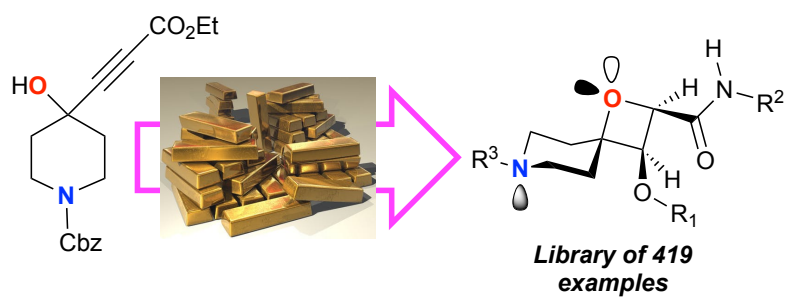

Abstract: A spirocyclic, $s p^{3}$-atom rich oxetane-containing scaffold was synthesised in just two steps via a gold catalysed propargylic alcohol rearrangement. The key gold cyclisation can be undertaken on a $40 \mathrm{~g}$ scale allowing the preparation of 419 lead-like compounds based on the scaffold for the European Lead Factory.

\section{Introduction}

Recent initiatives in drug discovery have focussed on the development of synthetic methodologies to low molecular weight, lead-like, $s p^{3}$-atom rich molecules; that have the potential for diverse functionalisation. ${ }^{1-3}$ The oxetane motif has been explored in drug discovery due to its impact on the 
physicochemical properties of biologically active molecules. ${ }^{4-6}$ Originally identified as isosteres for gemdimethyl groups increasing steric bulk without increased lipophilicity, ${ }^{5}$ oxetanes also act as bioiosteric replacements for carbonyls and morpholines (Figure 1 ). ${ }^{4}$
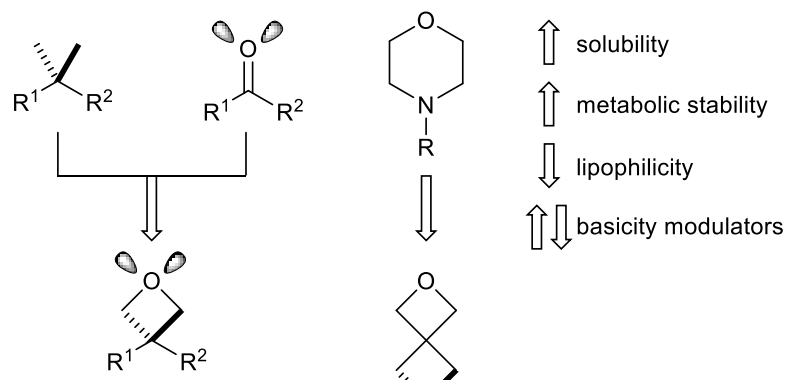

Figure 1: Bioisosteric roles of oxetanes in medicinal chemistry.

In particular, spirocyclic oxetanes (Figure 2) represent an interesting alternative scaffold due to their intrinsic high degree of three-dimensional character, rigidity and well defined vectors. ${ }^{7-11}$

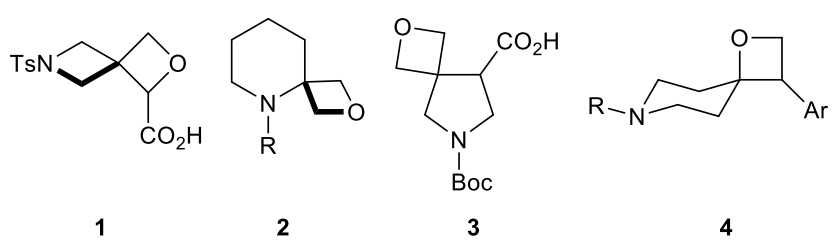

Figure 2: Recent examples of spirocyclic oxetane scaffolds.

Oxetanes can be prepared using a variety of methods including the intramolecular Williamson ether synthesis, ${ }^{10,12,13}$ the Paterno-Buchi reaction, ${ }^{14}$ intramolecular alkylation, ${ }^{15}$ or by gold catalysed rearrangement of propargylic alcohols. ${ }^{16}$ In keeping with our aim to prepare $s p^{3}$-atom rich scaffolds for drug discovery, as part of the European Lead Factory project, ${ }^{10,17-19}$ we identified the spirocyclic oxetane scaffold $\mathbf{5}$ for inclusion in the Joint European Compound Library (Figure 3). 

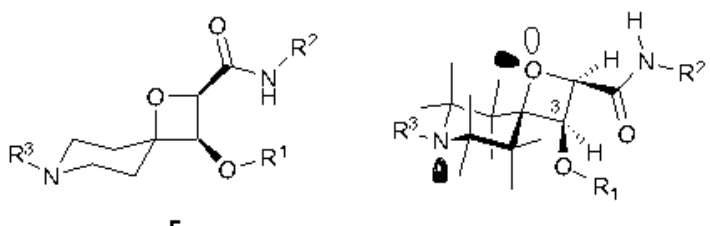

Figure 3: The 2-carboxyl-3-alkoxy-1-oxa-7-azaspiro[3,5]nonane ring system.

We foresaw that the 2-carboxyl-1-oxa-7-azaspiro[3,5]nonane scaffold $\mathbf{5}$ should be accessible by the aforementioned gold catalysed rearrangement of a propargylic alcohol (Figure 4), provided that the reaction was scalable and compatible with other functional groups. We now report the successful realisation of these goals that ultimately led to the synthesis of a library of 419 compounds in lead-like chemical space.
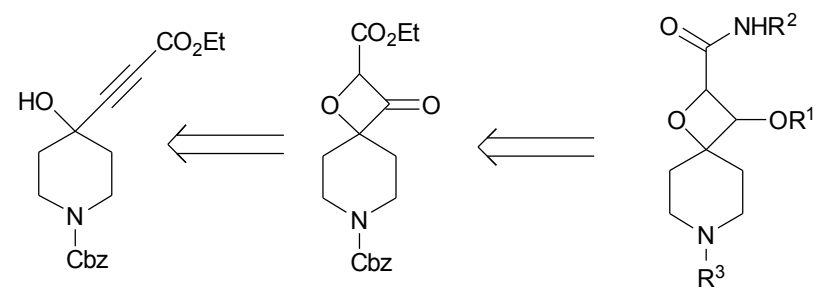

Library of 419 compounds prepared

Figure 4 Synthesis of key spirocyclic oxetane and functionalisation via gold catalysed rearrangement.

\section{Results and Discussion}

The propargylic alcohol 7 was prepared easily from Cbz-protected piperidinone 6 in $73 \%$ yield (Scheme 1). Alcohol 7 was then subjected to the gold catalysed rearrangement conditions, based on the literature procedure. ${ }^{16}$ Following these conditions we observed 58\% conversion into the desired product (Entry 1 , Table 1), with remaining starting material. Increasing the catalyst loading to 20 mol\% had little effect on this ratio (Entry 2, Table 1). Increasing the temperature to $60^{\circ} \mathrm{C}$ (Entry 3, Table 1 ) increased the yield to $74 \%$ with a significant reduction of remaining starting material. Pleasingly we also found that lowering 
the loading of the gold catalyst in this reaction from $5 \%$ (as in the literature procedure) to $2 \%$, gave the key scaffold, oxetan-3-one 8 , in a $65 \%$ yield on a $17 \mathrm{mmol}$ scale. On a $130 \mathrm{mmol}$ scale (43 g), oxetan-3one $\mathbf{8}$ was isolated in $76 \%$ yield. With the core scaffold $\mathbf{8}$ in hand, further diversification was attempted (Scheme 2).

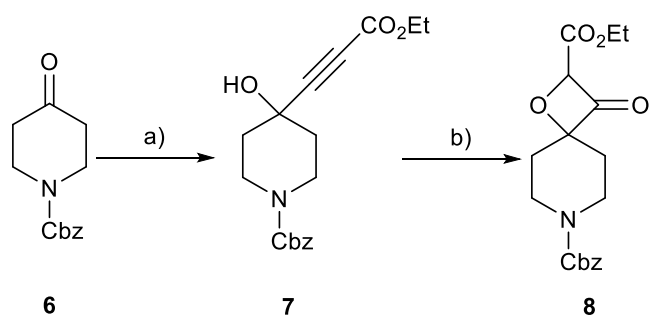

Scheme 1 Preparation of oxetan-3-one 8. Reagents and conditions: a) n-BuLi (3.0 eq.), ethyl propiolate (3.4 eq.), THF, $-70{ }^{\circ} \mathrm{C}, 2 \mathrm{~h}, 43 \mathrm{mmol}$ scale: $73 \%, 168 \mathrm{mmol}$ scale, $77 \%$; b) $\operatorname{iPrAuNTf}_{2}(2.1 \mathrm{~mol} \%), \mathrm{Tf}_{2} \mathrm{NH}(1.2$ eq.), 4-acetylpyridine $N$-oxide (2 eq.), 1,2-DCE, $60^{\circ} \mathrm{C}, 24 \mathrm{~h}, 17 \mathrm{mmol}$ scale: $65 \%, 130 \mathrm{mmol}$ scale: $76 \%$.

\begin{tabular}{|c|c|c|c|c|c|}
\hline Entry $^{a}$ & Time / h & $\overline{7}$ Temp $/{ }^{\circ} \mathrm{C}$ & $\mathrm{iPrAuNTf}_{2} / \mathrm{mol} \%$ & SM $7 / \%^{a}$ & Product $8 / \%^{a}$ \\
\hline 1 & 20 & 40 & 5 & 37 & 58 \\
\hline 2 & 20 & 40 & 20 & 27 & 62 \\
\hline 3 & 20 & 60 & 5 & 7 & 74 \\
\hline $4^{b}$ & 72 & 60 & 5 & 0 & 0 \\
\hline $5^{c}$ & 24 & 60 & 2 & 0 & 65 \\
\hline
\end{tabular}

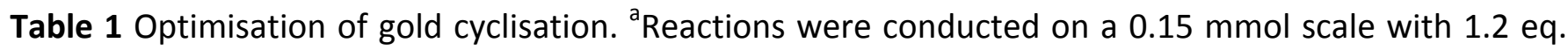
$\mathrm{Tf}_{2} \mathrm{NH}, 2$ eq. 4-acetylpyridine $\mathrm{N}$-oxide in anhydrous $1,2-\mathrm{DCE},{ }^{\mathrm{b}} 0.075 \mathrm{mmol}$ scale, ${ }^{\mathrm{c}} 17 \mathrm{mmol}$ scale. 
Methylation at C-4 with caesium carbonate and iodomethane was unsuccessful and resulted in the cleavage of the strained oxetan-3-one ring to tricarbonyl compound $\mathbf{9}$. This was based on observation of a new product formed with the same mass as the starting material, ${ }^{20}$ and similar transformations in the literature. ${ }^{21}$ Reductive amination of the ketone was attempted under a range of conditions, but only the opening of the oxetan-3-one ring to amide $\mathbf{1 0}$ or reduction to give alcohol $\mathbf{1 1}$ was observed (Scheme 2).

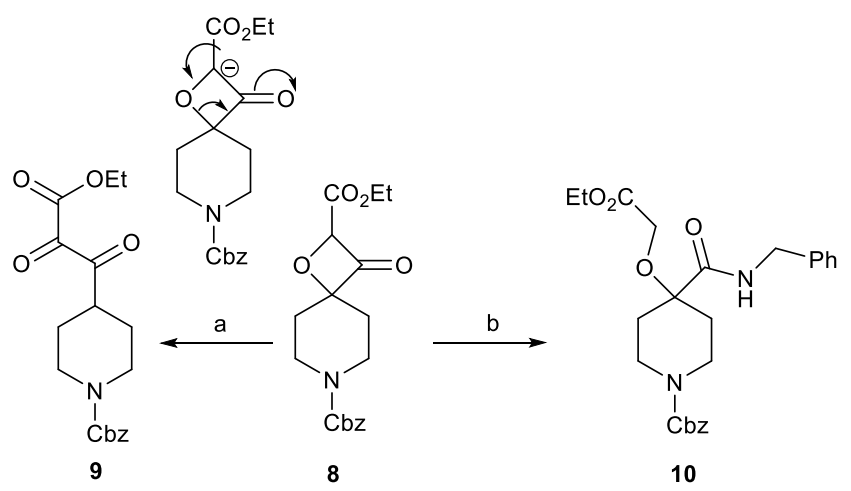

Scheme 2 Initial attempts at diversification of 1-oxa-7-azaspiro[3,5]nonane core 8. Reagents and conditions a) Mel, $\mathrm{Cs}_{2} \mathrm{CO}_{3}, \mathrm{DMF}, 87 \%$ (mass recovery). B) $\mathrm{BnNH}_{2}, \mathrm{Na}(\mathrm{OAc})_{3} \mathrm{BH}, 1,2-\mathrm{DCE}, 35 \%$.

Reduction of the ketone was more successful and the syn diastereomer of alcohol $\mathbf{1 1}$ was obtained with an excellent diastereoselectivity ( $>20: 1$ by ${ }^{1} \mathrm{H}$ NMR spectroscopy) using sodium triacetoxyborohydride with the addition of acetic acid (Scheme 3). The major diastereomer was isolated by chromatography and the syn stereochemistry was assigned based on ${ }^{1} \mathrm{H}$ NMR coupling constants. The syn diastereomer was found to have $\mathrm{a}^{3} \mathrm{~J}_{\mathrm{HH}}$ coupling constant of $7.1 \mathrm{~Hz}$, corresponding to the expected $0^{\circ}$ dihedral angle. In contrast, the minor diastereomer was found to have $\mathrm{a}^{3} \mathrm{~J}_{\mathrm{HH}}$ coupling constant of $5.5 \mathrm{~Hz}$ corresponding to the expected $60^{\circ}$ dihedral angle. ${ }^{22}$ O-Methylation of alcohol 11 could be achieved using iodomethane in the presence of silver oxide and a $72 \%$ yield of 12 was obtained on a small scale (200 $\mathrm{mg})$. This reaction, however, was not compatible with scale up conditions and on a $2.7 \mathrm{~g}$ scale, the yield dropped dramatically to just $23 \%$. For this reason, further diversification of ether $\mathbf{1 2}$ was not attempted. It was 
found that the ester functionality in $\mathbf{1 1}$ could be directly converted into an amide by treatment with an amine and $\mathrm{DABAL}_{-} \mathrm{M}_{3}$ (Scheme 4). ${ }^{23}$ In this way, benzyl amide 13 and isopropyl amide 14 were prepared in $71 \%$ and $69 \%$ yields respectively. Deprotection of the Cbz protecting group by hydrogenolysis $\left(\mathrm{H}_{2}, \mathrm{Pd} / \mathrm{C}\right)$ gave the amine scaffolds 15 and 16 ready for library synthesis.

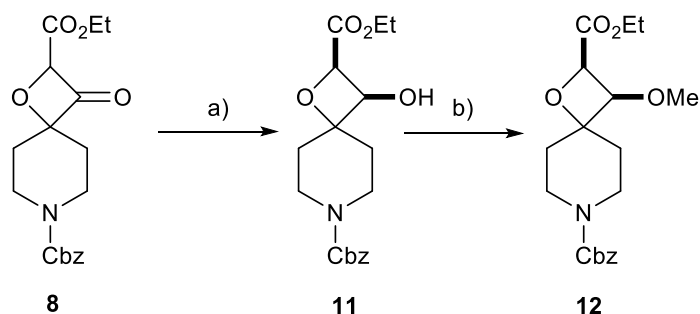

Scheme 3 Reduction and methylation of oxetan-3-one 8. Reagents and conditions: a) $\mathrm{Na}(\mathrm{OAc})_{3} \mathrm{BH}(2$ eq.), $\mathrm{AcOH}$ (1.7 eq.), 1,2-DCE, rt, 18 h, 77\%. b) $\mathrm{Ag}_{2} \mathrm{O}$ (5 eq.), Mel (150 eq.), $45^{\circ} \mathrm{C}, 48 \mathrm{~h}, 200 \mathrm{mg}$ scale: $72 \%$ 2.7 g scale: $23 \%$.

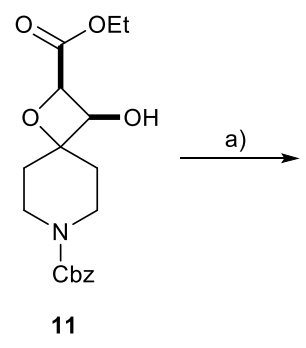

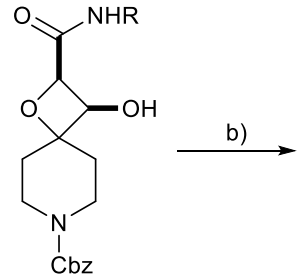

$13 \mathrm{R}=\mathrm{Bn}, 71 \%$ $14 \mathrm{R}=\mathrm{i} \operatorname{Pr}, 69 \%$

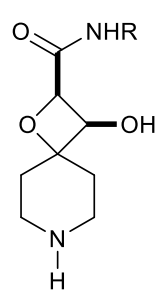

$15 \mathrm{R}=\mathrm{Bn}, 99 \%$ $16 \mathrm{R}=\mathrm{iPr}, 98 \%$

Scheme 4 Functionalising oxetan-3-ol 11. Reagents and conditions a) 1. DABAL-Me 3 (1.5 eq.), $\mathrm{RNH}_{2}(1.5$ eq.), THF, $40^{\circ} \mathrm{C}, 1$ h. $2.11, \mathrm{THF}, 65^{\circ} \mathrm{C}, 18$ h. b) $\mathrm{H}_{2}, \mathrm{Pd} / \mathrm{C}$ (10 wt\%), $\mathrm{CF}_{3} \mathrm{CH}_{2} \mathrm{OH}, \mathrm{rt}, 15 \mathrm{~h}$.

\subsection{Library synthesis}

The synthetic tractability of the amine cores 15 and 16 in library synthesis was tested on a small scale at Sygnature Discovery (Nottingham, UK) using high-throughput methods. A small library of 13 compounds 
was prepared by HATU mediated amide coupling to give amides $17 \mathbf{a}-\mathbf{c}$ and $\mathbf{1 8 a - b}$, reductive amination to give tertiary amines $\mathbf{1 7 d - f}$ and $\mathbf{1 8 c}-\mathbf{d}$, and reaction with sulfonyl chlorides to give sulfonamides $\mathbf{1 7 g}-\mathbf{h}$ and 18e (Scheme 5).

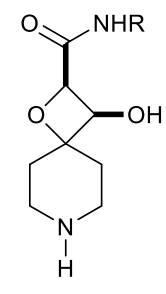

$15 \mathrm{R}=\mathrm{Bn}, 41 \%$ $16 \mathrm{R}=\mathrm{iPr}, 55 \%$ a), b) or c)<smiles>[R]NC(=O)[C@H]1OC2(CCN([R])CC2)[C@@H]1O</smiles>

17a-h $\mathrm{R}=\mathrm{Bn}$ 18a-e $\mathrm{R}=\mathrm{iPr}$

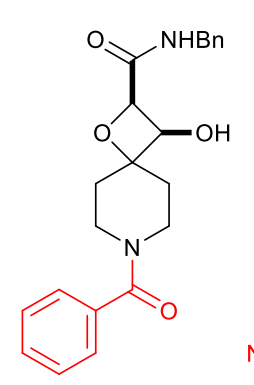

$17 a$

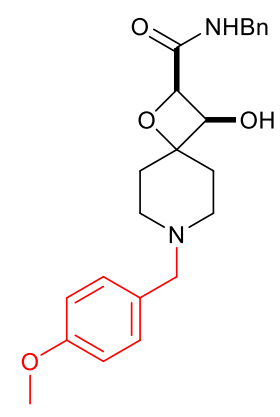

$17 e$

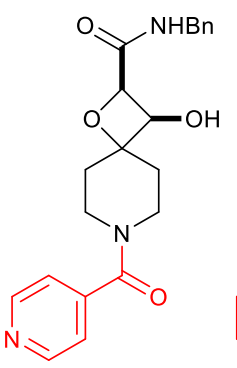

$17 b$
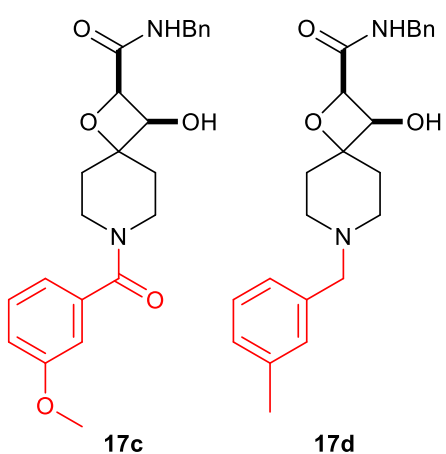

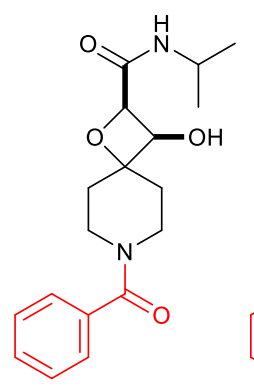

$18 a$

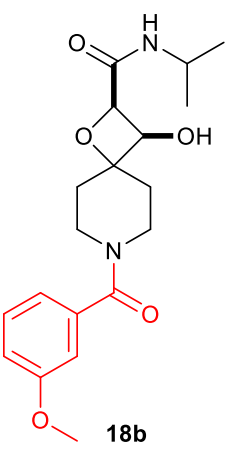

$17 d$
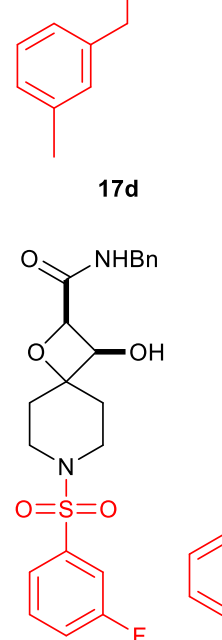

$17 \mathrm{~h}$<smiles>COc1ccc(S(=O)(=O)O)cc1</smiles>

$17 \mathrm{~g}$

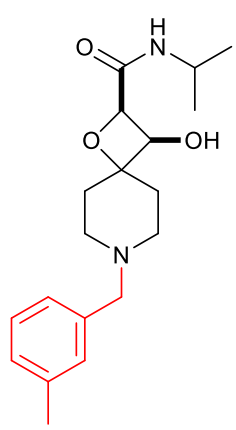

$18 c$
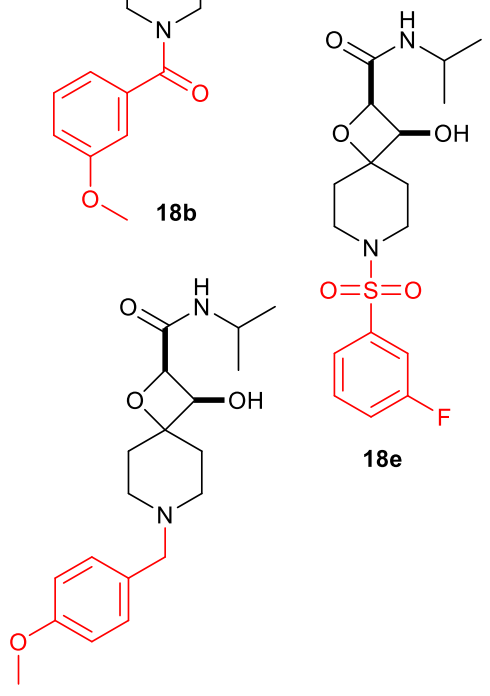

$\mathrm{O}=\mathrm{S}=\mathrm{O}$

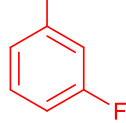

$18 \mathrm{e}$

Scheme 5 Library compounds synthesised by high-throughput methods. Reagents and conditions: a) carboxylic acid, i- $\mathrm{Pr}_{2} \mathrm{NEt}, \mathrm{HATU}, \mathrm{DMF}, 18 \mathrm{~h}$, rt.; b) aldehyde, $\mathrm{AcOH}, \mathrm{NMe}{ }_{4}(\mathrm{OAc})_{3} \mathrm{BH}, \mathrm{DMF}, 18 \mathrm{~h}, \mathrm{rt}$.; c) sulfonyl chloride, pyridine, DMF, $18 \mathrm{~h}$, rt.

The scaffolds prepared in this paper were developed for inclusion in the Joint European Compound Library (JECL) for the European Lead Factory, and therefore following the small-scale library synthesis, a 
full library of 419 compounds was prepared. The design of the library was chosen to consider the molecular properties of the compounds, including $\log \mathrm{P}$ and molecular weight and to avoid any potentially undesirable groups. The molecular weights of the compounds within the library were between 324 and 445 Da (Figure 5). The molecular weight of the core unfunctionalised scaffold is 202. When compared to two commercial libraries; Maybridge HitCreator and Maybridge HitFinder we can see that the oxetane library is more densely clustered in lead-like space compared to the commercial libraries (Figure 5). ${ }^{24}$ The compounds have a high fraction of $s p^{3}$ hybridised atoms with the majority between 60 and $70 \%$ with an average of $57 \%$; compared to $24 \%$ and $31 \%$ for the commercial HitFinder and HitCreator libraries respectively (Figure 6 and Table 2). Thus our oxetane library provides a focused set of compounds with more desirable "lead-like" lipophilicity with an $f^{\text {p3 }}$ expected of a candidate drug molecule.

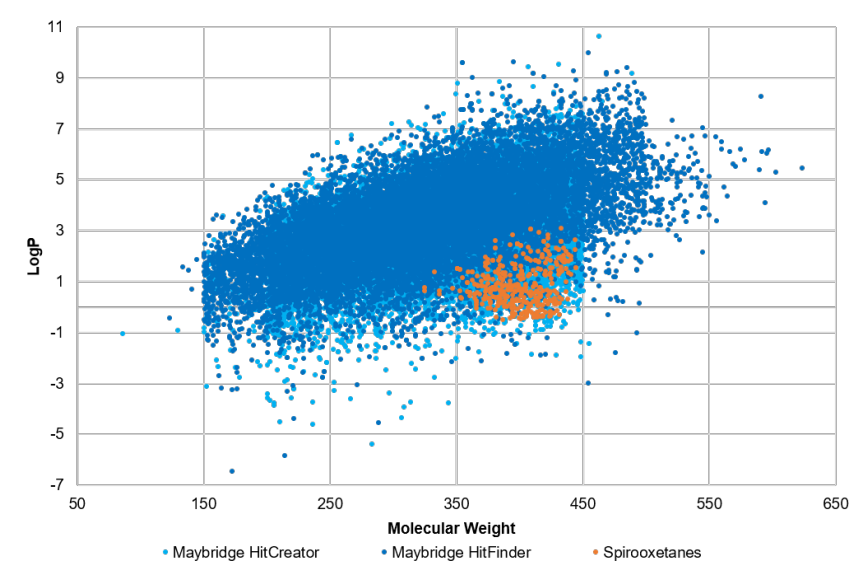

Figure 5 Plot of molecular weight versus cLogP for the prepared oxetane library and commercial libraries. 


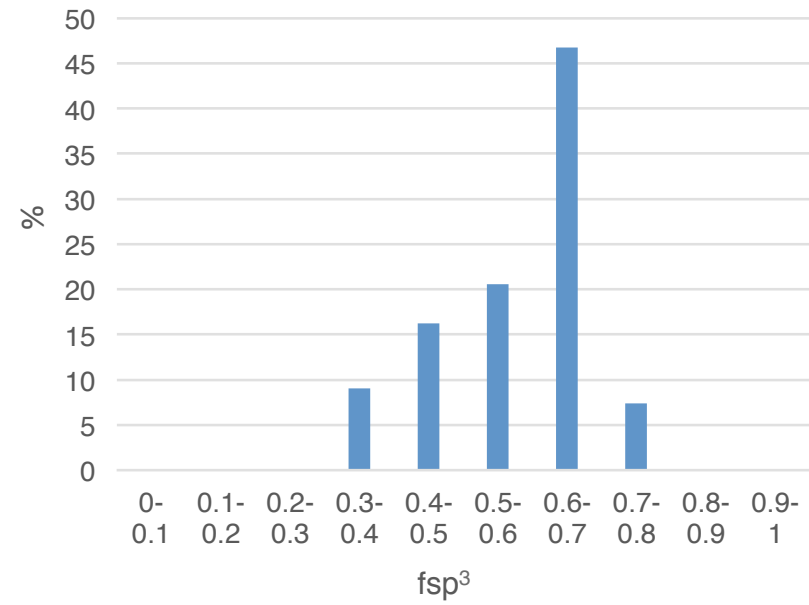

Figure 6 Plot showing fraction of $s p^{3}$ hybridised carbons.

\begin{tabular}{lccc}
\hline Library & Mean MW (Da) & Mean cLogP & Mean Fsp3 \\
\hline Oxetane Library & 399.40 & 0.89 & $57 \%$ \\
Maybridge HitFinder & 325.56 & 3.30 & $23 \%$ \\
Maybridge HitCreator & 340.17 & 2.87 & $30 \%$
\end{tabular}

Table 3: Comparison of key molecular properties for the oxetane library and two commercial libraries.

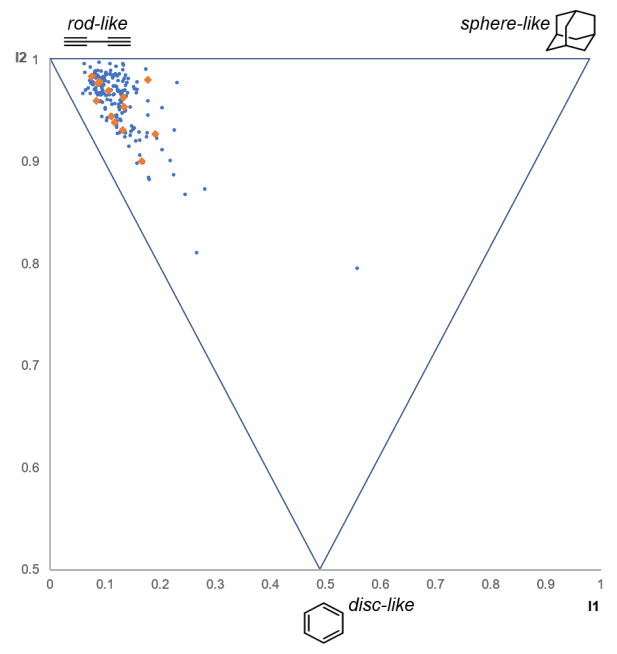

Figure 7 Principal moment of inertia plot of virtual library of oxetanes generated through LLAMA. Orange points represent compounds $17 \mathrm{a}-\mathrm{h}$ and 18a-e. 
We utilised the library modelling tool LLAMA to generate a principle moment of inertia plot of shape distribution for a virtual library of compounds (see ESI for full details), and the synthesised compounds 17a-h and 18a-e (Figure 7). ${ }^{25}$ The virtual library of molecules, along with the synthesised examples, occupy the rod-like area of molecular space; reflecting the overriding contribution of the core scaffold for molecular shape - allowing for lead optimisation with a variety of decorating groups without significantly changing the overall molecule shape.

\section{Conclusions}

In conclusion, we have applied the gold catalysed rearrangement of propargylic alcohols to the synthesis of functionalized spirocyclic oxetane-piperidines for drug discovery. The key gold rearrangement can be undertaken on a decagram scale to generate the oxetan-3-one intermediate with three points of functionalisation. The scaffold can be further elaborated to prepare compound libraries that are of importance to medicinal chemistry due to their rod-like structure. This methodology has enabled the synthesis of 419 novel chemical entities with attractive physicochemical properties, that are available through the open access JECL for lead generation to academic and industrial groups.

\section{Experimental Section}

For general experimental details, and protocols for library synthesis, see Electronic Supplementary Information.

\section{Benzyl 4-(3-ethoxycarbonylprop-1-yn-1-yl)-4-hydroxypiperidine-1-carboxylate, 7}




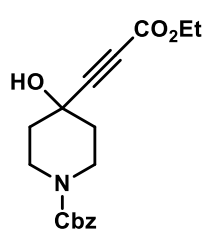

A solution of ethyl propiolate $(14.8 \mathrm{~mL}, 145.9 \mathrm{mmol})$ in THF $(120 \mathrm{~mL})$ was cooled to $-70{ }^{\circ} \mathrm{C}$ in an acetone/dry ice bath. To this was added $n$-butyllithium $(2.25 \mathrm{M}$ in hexanes, $57 \mathrm{~mL}, 128.2 \mathrm{mmol})$, dropwise over $1 \mathrm{~h}$ and the solution was stirred at $-70^{\circ} \mathrm{C}$ for $15 \mathrm{~min}$. After this time, a solution of $1-\mathrm{Cbz}-4-$ piperidone 6 (10.0 g, $42.9 \mathrm{mmol})$ in THF $(120 \mathrm{~mL})$ was added dropwise over an hour, ensuring that the temperature did not rise above $-70{ }^{\circ} \mathrm{C}$. The resultant solution was stirred at $-70{ }^{\circ} \mathrm{C}$ for $2 \mathrm{~h}$ until the disappearance of the starting material was observed by TLC ( $50 \%$ ethyl acetate in light petroleum). The reaction was quenched at $-70{ }^{\circ} \mathrm{C}$ by the dropwise addition of a aqueous ammonium chloride solution (saturated, $100 \mathrm{~mL}$ ) over $20 \mathrm{~min}$. The reaction mixture was warmed to room temperature extracted with ethyl acetate $(4 \times 100 \mathrm{~mL})$. The combined organic phases were washed with brine $(2 \times 100 \mathrm{~mL})$, dried $\left(\mathrm{MgSO}_{4}\right)$ and the solvent removed in vacuo to give a brown oil (21.2 g). Purification by column chromatography (40\% ethyl acetate in light petroleum) gave the title compound $\mathbf{7}$ as a yellow crystalline solid (10.42 g, 73\%): $\boldsymbol{R}_{\boldsymbol{f}} 0.47$ (40\% ethyl acetate in light petroleum, weakly UV active, $\mathrm{KMnO}_{4}$ active); $\mathbf{m p}$ 92-94 ${ }^{\circ} \mathrm{C}$; HRMS $\mathrm{m} / z\left(\mathrm{ESI}^{+}\right)$calcd. for $\mathrm{C}_{18} \mathrm{H}_{22} \mathrm{NO}_{5}[\mathrm{M}+\mathrm{H}]^{+}$requires 332.1492, found 332.1498, calcd. for $\mathrm{C}_{18} \mathrm{H}_{21} \mathrm{NNaO}_{5}[\mathrm{M}+\mathrm{Na}]^{+}$requires 354.1312 , found $354.1319 ; \mathbf{v}_{\max }(\mathrm{ATR}) / \mathrm{cm}^{-1} 3388,2227,1707,1673$, 1496, 1472, 1447, 1308, 1161, 1076, 1032, 812, 751; ${ }^{1} \mathrm{H}$ NMR $\left(400 \mathrm{MHz} ; \mathrm{CDCl}_{3}\right) \delta 7.39-7.32(5 \mathrm{H}, \mathrm{m}$, $\operatorname{ArH}), 5.13\left(2 \mathrm{H}, \mathrm{s}, \mathrm{CH}_{2} \mathrm{Ph}\right), 4.24\left(2 \mathrm{H}, \mathrm{q}, J \mathrm{~J} .2, \mathrm{OCH}_{2}\right), 3.80-3.77\left(2 \mathrm{H}, \mathrm{m}, \mathrm{CH}_{\mathrm{a}} \mathrm{H}_{\mathrm{b}}-2, \mathrm{CH}_{\mathrm{a}} \mathrm{H}_{\mathrm{b}}-6\right), 3.48-3.42$ $\left(2 \mathrm{H}, \mathrm{m}, \mathrm{CH}_{\mathrm{a}} \mathrm{H}_{\mathrm{b}}-2, \mathrm{CH}_{\mathrm{a}} \mathrm{H}_{\mathrm{b}}-6\right), 2.33(1 \mathrm{H}, \mathrm{br} \mathrm{s}, \mathrm{OH}), 2.02-1.91\left(2 \mathrm{H}, \mathrm{m}, \mathrm{CH}_{\mathrm{a}} \mathrm{H}_{\mathrm{b}}-3, \mathrm{CH}_{\mathrm{a}} \mathrm{H}_{\mathrm{b}}-5\right), 1.85-1.73(2 \mathrm{H}, \mathrm{m}$, $\left.\mathrm{CH}_{\mathrm{a}} \mathrm{H}_{\mathrm{b}}-3, \mathrm{CH}_{\mathrm{a}} \mathrm{H}_{\mathrm{b}}-5\right), 1.31\left(3 \mathrm{H}, \mathrm{t}, J 7.2, \mathrm{CH}_{2} \mathrm{CH}_{3}\right) ;{ }^{13} \mathrm{C}$ NMR $\left(100 \mathrm{MHz} ; \mathrm{CDCl}_{3}\right) \delta 155.2,153.4,136.7,128.7$, $128.2,128.0,88.4,76.8,67.5,66.4,62.5,40.5,38.1,14.1$.

\section{7-Benzyl 2-ethyl 3-oxo-1-oxa-7-azaspiro[3.5]nonane-2,7-dicarboxylate, 8}




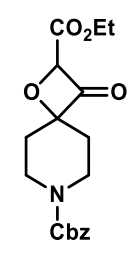

A solution of alkyne 7 (5.63 g, $17.0 \mathrm{mmol})$ in dry dichloroethane (68 $\mathrm{mL}$ ) was prepared under nitrogen. To this was added sequentially, 4-acetylpyridine $\mathrm{N}$-oxide (4.66 $\mathrm{g}, 34.0 \mathrm{mmol}$ ), a solution of trifluoromethanesulfonimide $(5.74 \mathrm{~g}, 20.4 \mathrm{mmol})$ in dry dichloroethane $(100 \mathrm{~mL})$ and $i \operatorname{PrAuNTf} 2(0.368 \mathrm{~g}$, $0.43 \mathrm{mmol})$. The solution was then heated to $60{ }^{\circ} \mathrm{C}$ and stirred at this temperature for $24 \mathrm{~h}$. After this time, the solvent was removed in vacuo. Purification by column chromatography $(40 \%$ ethyl acetate in light petroleum) to give the title compound 8 as a yellow oil ( $3.83 \mathrm{~g}, 65 \%): \boldsymbol{R}_{f} 0.65$ (50\% ethyl acetate in light petroleum, UV inactive, weakly $\mathrm{KMnO}_{4}$ active); HRMS $\mathrm{m} / z\left(\mathrm{ESI}^{+}\right)$calcd. for $\mathrm{C}_{18} \mathrm{H}_{21} \mathrm{NNaO}_{6}[\mathrm{M}+\mathrm{Na}]^{+}$ requires 370.1261 , found $370.1259 ; \mathbf{v}_{\max }(A T R) / \mathrm{cm}^{-1} 1823,1747,1695,1429,1237,1198,1003,907,727$; ${ }^{1} \mathrm{H}$ NMR $\left(400 \mathrm{MHz}, \mathrm{CDCl}_{3}\right) \delta 7.43-7.27(5 \mathrm{H}, \mathrm{m}, \mathrm{ArH}), 5.72(1 \mathrm{H}, \mathrm{s}, \mathrm{CH}), 5.13\left(2 \mathrm{H}, \mathrm{s}, \mathrm{CH}_{2} \mathrm{Ph}\right), 4.37-4.20$ $\left(2 \mathrm{H}, \mathrm{m}, \mathrm{CH}_{2}\right), 3.76-3.56\left(4 \mathrm{H}, \mathrm{m}, \mathrm{CH}_{2}\right), 2.15-1.88\left(4 \mathrm{H}, \mathrm{m}, \mathrm{CH}_{2}\right), 1.31\left(3 \mathrm{H}, \mathrm{t}, \mathrm{J} 7.1, \mathrm{CH}_{2} \mathrm{CH}_{3}\right) ;{ }^{13} \mathrm{C} \mathrm{NMR}(100$ $\left.\mathrm{MHz}_{\mathrm{CDCl}_{3}}\right) \delta 196.4,165.0,155.2,136.6,128.7,128.3,128.1,108.0,93.7,67.6,62.6,40.1(2 \mathrm{C}), 31.9$, $31.5,14.3$.

\section{Benzyl 4-(benzylcarbamoyl)-4-(2-ethoxy-2-oxoethoxy)piperidine-1-carboxylate, 10}

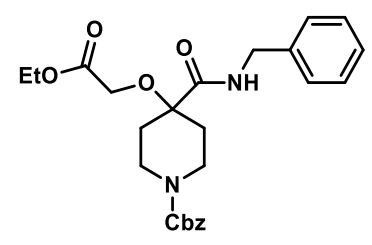

A solution of the ketone $8(52 \mathrm{mg}, 0.15 \mathrm{mmol})$ in dry dichloroethane $(3.3 \mathrm{~mL})$ was prepared under nitrogen. To this was added benzylamine $(24 \mathrm{mg}, 25 \mu \mathrm{L}, 0.22 \mathrm{mmol}$ ) followed by glacial acetic acid (20 $\mu \mathrm{L}, 0.35 \mathrm{mmol}$ ) and the reaction mixture was stirred at room temperature for $2 \mathrm{~h}$. After this time sodium triacetoxyborohydride $(64 \mathrm{mg}, 0.30 \mathrm{mmol}$ ) was added. The suspension was then stirred at room 
temperature for an additional $18 \mathrm{~h}$ until the disappearance of the starting material was confirmed by TLC ( $50 \%$ ethyl acetate in light petroleum). The reaction was quenched by the addition of water $(5 \mathrm{~mL})$ and stirred for $1 \mathrm{~h}$. The reaction was extracted with dichloromethane $(3 \times 5 \mathrm{~mL})$ and the organic phases were combined, dried $\left(\mathrm{MgSO}_{4}\right)$ and the solvent removed in vacuo. Purification by column chromatography (50\% ethyl acetate in light petroleum to $100 \%$ ethyl acetate) gave the title compound 10 as a colourless oil ( $24 \mathrm{mg}, 35 \%): \boldsymbol{R}_{\boldsymbol{f}} 0.70$ (50\% ethyl acetate in light petroleum, weakly UV active, $\mathrm{KMnO}_{4}$ active); HRMS $\mathrm{m} / z\left(\mathrm{ESI}^{+}\right)$calcd. for $\mathrm{C}_{24} \mathrm{H}_{31} \mathrm{~N}_{2} \mathrm{O}_{5}[\mathrm{M}+\mathrm{H}]^{+}$requires 427.2227, found 427.2230; $\mathbf{v}_{\max }$ $($ ATR $) / \mathrm{cm}^{-1} 1722,1672,1640,1537,1450,1242,1220,1000 ;{ }^{1} \mathrm{H}$ NMR $\left(500 \mathrm{MHz}, \mathrm{CDCl}_{3}\right) \delta 7.59(1 \mathrm{H}, \mathrm{d}, J$ 5.9, NH), $7.30-7.15(10 \mathrm{H}, \mathrm{m}, \mathrm{ArH}), 5.05\left(2 \mathrm{H}, \mathrm{s}, \mathrm{OCH}_{2} \mathrm{Ph}\right), 4.22\left(2 \mathrm{H}, \mathrm{d}, \mathrm{J} 6.0, \mathrm{NCH}_{2} \mathrm{Ph}\right), 4.03-3.87(6 \mathrm{H}, \mathrm{m}$, $\left.\mathrm{OCH}_{2} \mathrm{CO}_{2} \mathrm{Et}, \mathrm{OCH}_{2} \mathrm{CH}_{3}, \mathrm{CH}_{2}\right), 3.15-2.97\left(2 \mathrm{H}, \mathrm{m}, \mathrm{CH}_{2}\right), 2.11-1.96\left(2 \mathrm{H}, \mathrm{m}, \mathrm{CH}_{2}\right), 1.78-1.62\left(2 \mathrm{H}, \mathrm{m}, \mathrm{CH}_{2}\right)$, $1.12\left(3 \mathrm{H}, \mathrm{t}, \mathrm{J}\right.$ 7.6, $\left.\mathrm{CH}_{2} \mathrm{CH}_{3}\right) ;{ }^{13} \mathrm{C}$ NMR $\left(125 \mathrm{MHz} ; \mathrm{CDCl}_{3}\right) \delta 173.0,170.2,155.2,138.3,136.7,128.7,128.5$, $128.0,127.9,127.8,127.5,80.2,67.2,62.7,61.6,43.3,39.7,31.7,14.0$.

\section{7-Benzyl 2-ethyl (2R*,3R*)-3-hydroxy-1-oxa-7-azaspiro[3.5]nonane-2,7-dicarboxylate, 11}<smiles>CCOC(O)C1(O)CCN(C)CC1</smiles>

A solution of the ketone $8(3.51 \mathrm{~g}, 10.1 \mathrm{mmol})$ in dry dichloroethane $(222 \mathrm{~mL})$ was prepared under nitrogen. To this was added sodium triacetoxyborohydride ( $4.29 \mathrm{~g}, 20.2 \mathrm{mmol})$ immediately followed by glacial acetic acid $(0.98 \mathrm{~mL}, 17.2 \mathrm{mmol})$ and the suspension was stirred at room temperature for $17 \mathrm{~h}$. After this time, additional sodium triacetoxyborohydride $(2.14 \mathrm{~g}, 10.1 \mathrm{mmol})$ and glacial acetic acid $(0.5$ $\mathrm{mL}, 8.1 \mathrm{mmol}$ ) were added. The suspension was then stirred at room temperature for an additional $18 \mathrm{~h}$ until the disappearance of the starting material was confirmed by TLC ( $50 \%$ ethyl acetate in light petroleum). The reaction was quenched by the addition of water $(100 \mathrm{~mL})$ and stirred for $15 \mathrm{~min}$. The 
reaction was extracted with dichloromethane $(3 \times 100 \mathrm{~mL})$ and the organic phases were combined, dried $\left(\mathrm{MgSO}_{4}\right)$ and the solvent removed in vacuo to give a pale yellow oil (3.67 g). Analysis of the crude reaction mixture by ${ }^{1} \mathrm{H}$ NMR spectroscopy showed a 20:1 ratio of diastereomers (syn:anti). Purification by column chromatography (50\% ethyl acetate in light petroleum) gave the major diastereomer $\mathbf{1 1}$ as a white oily solid ( $2.70 \mathrm{~g}, 77 \%$ ): $\boldsymbol{R}_{\boldsymbol{f}} 0.21$ ( $50 \%$ ethyl acetate in light petroleum, UV inactive, $\mathrm{KMnO}_{4}$ active); HRMS $\mathrm{m} / \mathrm{z}$ (ESI ${ }^{+}$) calcd. for $\mathrm{C}_{18} \mathrm{H}_{24} \mathrm{NO}_{6}[\mathrm{M}+\mathrm{H}]^{+}$requires 350.1598 , found 350.1599 , calcd. for $\mathrm{C}_{18} \mathrm{H}_{23} \mathrm{NNaO}_{6}$ $[\mathrm{M}+\mathrm{Na}]^{+}$requires 372.1418, found $372.1415 ; \mathbf{v}_{\max }(\mathrm{ATR}) / \mathrm{cm}^{-1} 3384,1721,1702,1422,1222,1057 ;{ }^{1} \mathbf{H}$ NMR (400 MHz, CDCl $)$ ) $7.38-7.29(5 \mathrm{H}, \mathrm{m}, \mathrm{ArH}), 5.12\left(2 \mathrm{H}, \mathrm{s}, \mathrm{CH}_{2} \mathrm{Ph}\right), 5.08(1 \mathrm{H}, \mathrm{d}, J 7.1, \mathrm{CH}), 4.58(1 \mathrm{H}, \mathrm{d}$, J 7.1, CH), $4.35-4.23\left(2 \mathrm{H}, \mathrm{m}, \mathrm{CH}_{2}\right), 3.73-3.62\left(2 \mathrm{H}, \mathrm{m}, \mathrm{CH}_{2}\right), 3.47\left(2 \mathrm{H}, \mathrm{tdd}, J 13.2,9.2,3.7, \mathrm{CH}_{2}\right), 3.02(1 \mathrm{H}$, br s, OH), $2.10-1.72\left(4 \mathrm{H}, \mathrm{m}, \mathrm{CH}_{2}\right), 1.31\left(3 \mathrm{H}, \mathrm{t}, \mathrm{J} 7.1, \mathrm{CH}_{2} \mathrm{CH}_{3}\right) ;{ }^{13} \mathrm{C}$ NMR $\left(100 \mathrm{MHz}, \mathrm{CDCl}_{3}\right) \delta 170.5,155.4$, $136.8,128.6,128.2,128.0,89.0,78.8,72.2,67.3,61.7,40.1,40.0,36.6,30.8,14.4$.

\section{7-Benzyl 2-ethyl (2R*,3R*)-3-methoxy-1-oxa-7-azaspiro[3.5]nonane-2,7-dicarboxylate, 12}

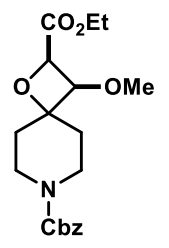

Silver(II) oxide (660 mg) was added to a solution of alcohol 11 in iodomethane $(12.2 \mathrm{~g}, 5.3 \mathrm{~mL}, 86.0$ $\mathrm{mmol}$ ). The reaction mixture was stirred at $45^{\circ} \mathrm{C}$ for $48 \mathrm{~h}$. Following this time, the reaction mixture was cooled to room temperature and filtered under vaccum, the filtrate was washed with dichloromethane $(3 \times 10 \mathrm{~mL})$. The solvent was removed in vacuo. Purification by column chromatography $(50 \%$ ethyl acetate in light petroleum) to give the title compound 12 as a colourless oil (150 mg, 72\%). $\boldsymbol{R}_{\boldsymbol{f}} 0.60$ (50\% ethyl acetate in light petroleum, UV inactive, $\mathrm{KMnO}_{4}$ active); $\mathrm{HRMS} \mathrm{m} / \mathrm{z}\left(\mathrm{ESI}{ }^{+}\right.$) calcd. for $\mathrm{C}_{19} \mathrm{H}_{25} \mathrm{NNaO}_{6}$ $[\mathrm{M}+\mathrm{Na}]^{+}$requires 386.1574 , found $386.1575 ; \boldsymbol{v}_{\max }(\mathrm{ATR}) / \mathrm{cm}^{-1} 2933,1750,1693,1428,1226,1192,1131$, 1038, 697; ${ }^{1} \mathrm{H}$ NMR $\left(400 \mathrm{MHz}, \mathrm{CDCl}_{3}\right) \delta 7.38-7.29(5 \mathrm{H}, \mathrm{m}, \mathrm{ArH}), 5.13(1 \mathrm{H}, \mathrm{d}, J$ 7.3, CHOMe), $4.28(2 \mathrm{H}, \mathrm{q}, J$ 
7.3, $\left.\mathrm{CH}_{2}\right), 4.13(1 \mathrm{H}, \mathrm{d}, \mathrm{J} 7.3, \mathrm{CH}), 3.81-3.68\left(2 \mathrm{H}, \mathrm{m}, \mathrm{CH}_{2}\right), 3.47-3.36\left(2 \mathrm{H}, \mathrm{m}, \mathrm{CH}_{2}\right), 3.36(3 \mathrm{H}, \mathrm{s}, \mathrm{OCH})_{3}$, $2.14-1.77\left(4 \mathrm{H}, \mathrm{m}, \mathrm{CH}_{2}\right), 1.31\left(3 \mathrm{H}, \mathrm{t}, J \mathrm{~J} .3, \mathrm{CH}_{2} \mathrm{CH}_{3}\right) ;{ }^{13} \mathrm{C}$ NMR $\left(100 \mathrm{MHz} ; \mathrm{CDCl}_{3}\right) \delta 170.0,155.4,136.9$, $128.6,128.1,128.0,89.0,81.0,79.2,67.3,61.3,59.4,40.1,40.0,37.2,30.9,14.4$.

Benzyl $\left(2 R^{*}, 3 R^{*}\right)$-2-(benzylcarbamoyl)-3-hydroxy-1-oxa-7-azaspiro[3.5]nonane-7-carboxylate, 13

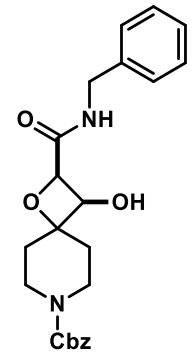

Benzylamine $(87 \mu \mathrm{L}, 0.80 \mathrm{mmol})$ was added to a suspension of DABAL-Me $\mathrm{M}_{3}(0.21 \mathrm{~g}, 0.80 \mathrm{mmol})$ in dry THF (4.3 mL) under nitrogen in a Schlenk flask. The flask was sealed and the reaction mixture was stirred at $40{ }^{\circ} \mathrm{C}$ for $1 \mathrm{~h}$. After this time, a solution of the ester 11 (187 mg, $\left.0.54 \mathrm{mmol}\right)$ in dry THF (2 mL) was added and the reaction mixture was stirred at $65^{\circ} \mathrm{C}$ for $20 \mathrm{~h}$. The disappearance of the starting material was observed by TLC (100\% ethyl acetate) and the reaction mixture was cooled to room temperature. Aqueous ammonium chloride solution (saturated, $10 \mathrm{~mL}$ ) was added and the product was extracted with ether $(3 \times 10 \mathrm{~mL})$. The solvent was removed in vacuo. Purification by column chromatography $(100 \%$ ethyl acetate) to give the title compound 13 as a colourless oil (160 mg, 71\%). $\boldsymbol{R}_{\boldsymbol{f}} 0.41$ (100\% ethyl acetate, weakly UV active, $\mathrm{KMnO}_{4}$ active); HRMS $\mathrm{m} / \mathrm{z}(\mathrm{ESI})^{+}$) calcd. for $\mathrm{C}_{23} \mathrm{H}_{27} \mathrm{~N}_{2} \mathrm{O}_{5}[\mathrm{M}+\mathrm{H}]^{+}$requires 411.1914, found 411.1913, calcd. for $\mathrm{C}_{23} \mathrm{H}_{26} \mathrm{~N}_{2} \mathrm{NaO}_{5}[\mathrm{M}+\mathrm{Na}]^{+}$requires 433.1734 , found $433.1731 ; \boldsymbol{v}_{\max }$

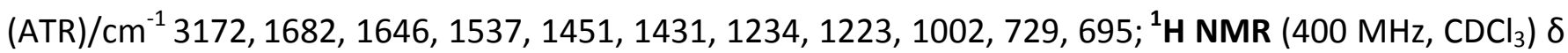
$7.37-7.29(10 \mathrm{H}, \mathrm{m}, \mathrm{ArH}), 7.17(1 \mathrm{H}, \mathrm{t}, J 6.0, \mathrm{NH}), 5.11\left(2 \mathrm{H}, \mathrm{s}, \mathrm{CH}_{2} \mathrm{Ph}\right), 4.98(1 \mathrm{H}, \mathrm{d}, J$ 6.6, $\mathrm{CH}), 4.64(1 \mathrm{H}, \mathrm{dd}$, J 15.0, 6.0, $\left.\mathrm{NCH}_{a} \mathrm{H}_{\mathrm{b}} \mathrm{Ph}\right), 4.56(1 \mathrm{H}, \mathrm{d}, J$ 6.6, $\mathrm{CH}), 4.44\left(1 \mathrm{H}, \mathrm{dd}, J\right.$ 15.0, 6.0, $\left.\mathrm{NCH}_{\mathrm{a}} H_{b} \mathrm{Ph}\right), 4.05(1 \mathrm{H}, \mathrm{br} \mathrm{s}, \mathrm{OH})$, $3.60-3.43\left(4 \mathrm{H}, \mathrm{m}, \mathrm{CH}_{2}\right), 1.98\left(1 \mathrm{H}, \mathrm{dt}, \mathrm{J} 12.8,5.7, \mathrm{CH}_{\mathrm{a}} \mathrm{H}_{\mathrm{b}}\right), 1.83\left(2 \mathrm{H}, \mathrm{br} \mathrm{s}, \mathrm{CH}_{2}\right), 1.76-1.69\left(1 \mathrm{H}, \mathrm{m}, \mathrm{CH}_{\mathrm{a}} H_{\mathrm{b}}\right)$; 
${ }^{13} \mathrm{C}$ NMR $\left(100 \mathrm{MHz}_{\mathrm{C}} \mathrm{CDCl}_{3}\right) \delta 170.5,155.3,137.5,136.8,129.0,128.7,128.2,128.0,127.9,127.6,88.5$, 79.0, 71.6, 67.4, 43.0, 40.33, 40.26, 36.5, 31.5.

\section{Benzyl $\left(2 R^{*}, 3 R^{*}\right)-3-h y d r o x y-2-($ isopropylcarbamoyl)-1-oxa-7-azaspiro[3.5]nonane-7-carboxylate, 14}

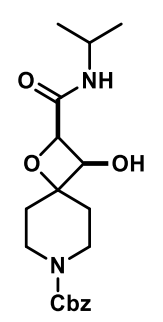

iso-Propylamine $(74 \mu \mathrm{L}, 0.86 \mathrm{mmol})$ was added to a suspension of $\mathrm{DABAL}^{-\mathrm{Me}_{3}}$ $(220 \mathrm{mg}, 0.86 \mathrm{mmol})$ in dry THF $(4.6 \mathrm{~mL})$ under nitrogen in a Schlenk flask. The flask was sealed and the reaction mixture was stirred at $40{ }^{\circ} \mathrm{C}$ for $1 \mathrm{~h}$. After this time, a solution of the ester $\mathbf{1 1}(200 \mathrm{mg}, 0.57$ mmol) in dry THF $(2 \mathrm{~mL})$ was added and the reaction mixture was stirred at $65{ }^{\circ} \mathrm{C}$ for $20 \mathrm{~h}$. The disappearance of the starting material was observed by TLC (100\% ethyl acetate) and the reaction mixture was cooled to room temperature. Aqueous ammonium chloride solution (saturated, $10 \mathrm{~mL}$ ) was added and the product was extracted with ether $(3 \times 10 \mathrm{~mL})$. The solvent was removed in vacuo. Purification by column chromatography ( $100 \%$ ethyl acetate) to give the title compound 14 as a colourless oil (140 mg, 69\%). $\boldsymbol{R}_{\boldsymbol{f}} 0.28$ (100\% ethyl acetate, weakly UV active, $\mathrm{KMnO}_{4}$ active); HRMS $\mathrm{m} / \mathrm{z}$ $\left(\mathrm{ESI}^{+}\right.$) calcd. for $\mathrm{C}_{19} \mathrm{H}_{27} \mathrm{~N}_{2} \mathrm{O}_{5}[\mathrm{M}+\mathrm{H}]^{+}$requires 363.1914, found 363.1906, calcd. for $\mathrm{C}_{19} \mathrm{H}_{26} \mathrm{~N}_{2} \mathrm{NaO}_{5}[\mathrm{M}+\mathrm{Na}]^{+}$ requires 385.1734 , found $385.1734 ; \mathbf{v}_{\max }(A T R) / \mathrm{cm}^{-1} 3328,1652(2), 1532,1428,1223,998,729 ;{ }^{1} \mathbf{H} \mathbf{N M R}$ $\left(400 \mathrm{MHz}, \mathrm{CDCl}_{3}\right) \delta 7.38-7.30(5 \mathrm{H}, \mathrm{m}, \mathrm{ArH}), 6.69\left(1 \mathrm{H}, \mathrm{d}, \mathrm{J}\right.$ 8.4, NH), $5.12\left(2 \mathrm{H}, \mathrm{s}, \mathrm{CH}_{2} \mathrm{Ph}\right), 4.87(1 \mathrm{H}, \mathrm{d}, J 6.4$, $\mathrm{CH}), 4.59-4.56(2 \mathrm{H}, \mathrm{m}, \mathrm{OH}$ and $\mathrm{CH}), 4.13(1 \mathrm{H}, \mathrm{dsept}, \mathrm{J} 8.4,6.6, \mathrm{CH}), 3.66-3.44\left(4 \mathrm{H}, \mathrm{m}, \mathrm{CH}_{2}\right), 2.03-1.77$ $\left(4 \mathrm{H}, \mathrm{m}, \mathrm{CH}_{2}\right), 1.21\left(3 \mathrm{H}, \mathrm{d}, J\right.$ 6.6, $\left.\mathrm{CH}_{3}\right), 1.17\left(3 \mathrm{H}, \mathrm{d}, J\right.$ 6.6, $\left.\mathrm{CH}_{3}\right) ;{ }^{13} \mathrm{C} \mathrm{NMR}\left(100 \mathrm{MHz} ; \mathrm{CDCl}_{3}\right) \delta 169.7,155.3$, $136.8,128.6,128.1,128.0,88.6,79.3,71.4,67.3,41.2,40.4,40.3,36.6,31.5,23.0,22.7$. 
$\left(2 R^{*}, 3 R^{*}\right)-N-B e n z y l-3-h y d r o x y-1-o x a-7-a z a s p i r o[3.5]$ nonane-2-carboxamide, 15

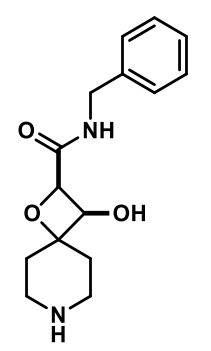

Palladium on carbon $(10 \%, 44 \mathrm{mg}$ ) was added to a solution of amide 12 (440 mg, $1.07 \mathrm{mmol}$ ) in trifluoroethanol $(20 \mathrm{~mL})$. The flask was evacuated and a balloon of hydrogen introduced. The suspension was then stirred at room temperature for $26 \mathrm{~h}$. After this time, the disappearance of the starting material was observed by TLC. The reaction mixture was filtered through Celite and extracted with dichloromethane $(3 \times 10 \mathrm{~mL})$. The solvent was removed in vacuo to give the title compound 15 as a white crystalline solid (291 mg, 99\%): $\mathrm{mp} \mathrm{69-70}{ }^{\circ} \mathrm{C}$; HRMS $\mathrm{m} / \mathrm{z}(\mathrm{ESI})^{+}$) calcd. for $\mathrm{C}_{15} \mathrm{H}_{21} \mathrm{~N}_{2} \mathrm{O}_{3}[\mathrm{M}+\mathrm{H}]^{+}$ requires 277.1547, found 277.1544, calcd. for $\mathrm{C}_{15} \mathrm{H}_{20} \mathrm{~N}_{2} \mathrm{NaO}_{3}[\mathrm{M}+\mathrm{Na}]^{+}$requires 299.1366, found 299.1362; $\mathbf{v}_{\max }(A T R) / \mathrm{cm}^{-1} 3250,2923,1652,1526,1128,992,730,698 ;{ }^{1} \mathbf{H} \mathbf{N M R}\left(400 \mathrm{MHz}, \mathrm{CDCl}_{3}\right) \delta 7.36$ - $7.28(5 \mathrm{H}, \mathrm{m}, \mathrm{ArH}), 7.22\left(1 \mathrm{H}, \mathrm{t}, J\right.$ 6.0, NH), $4.98(1 \mathrm{H}, \mathrm{d}, J$ 7.0, $\mathrm{CH}), 4.62\left(1 \mathrm{H}, \mathrm{dd}, J\right.$ 15.0, 6.0, $\left.\mathrm{NCH}_{a} \mathrm{H}_{\mathrm{b}} \mathrm{Ph}\right)$, $4.57(1 \mathrm{H}, \mathrm{d}, J 7.0, \mathrm{CH}), 4.44\left(1 \mathrm{H}, \mathrm{dd}, J 15.0,6.0, \mathrm{NCH}_{\mathrm{a}} \mathrm{H}_{b} \mathrm{Ph}\right), 3.01-2.79\left(6 \mathrm{H}, \mathrm{m}, \mathrm{OH}, \mathrm{NH}\right.$ and $\left.2 \times \mathrm{CH}_{2}\right), 2.09$ - $2.03\left(1 \mathrm{H}, \mathrm{m}, \mathrm{CH}_{2}\right), 1.94-1.81\left(2 \mathrm{H}, \mathrm{m}, \mathrm{CH}_{2}\right), 1.75-1.68\left(1 \mathrm{H}, \mathrm{m}, \mathrm{CH}_{2}\right) ;{ }^{13} \mathrm{C}$ NMR $\left(100 \mathrm{MHz} ; \mathrm{CDCl}_{3}\right)$ 170.6, $137.7,128.9,127.7,127.6,88.8,79.2,71.9,43.0,42.7,42.5,37.5,32.3$.

$\left.2 R^{*}, 3 R^{*}\right)$-3-Hydroxy-N-isopropyl-1-oxa-7-azaspiro[3.5]nonane-2-carboxamide, 16<smiles>CC(C)NC(=O)C1OC2(CCNCC2)C1O</smiles> 
Palladium on carbon $(10 \%, 58 \mathrm{mg}$ ) was added to a solution of amide 13 (580 mg, $1.60 \mathrm{mmol}$ ) in trifluoroethanol $(20 \mathrm{~mL})$. The flask was evacuated and a balloon of hydrogen introduced. The suspension was then stirred at room temperature for $24 \mathrm{~h}$. After this time, the disappearance of the starting material was observed by TLC. The reaction mixture was filtered through Celite and extracted with dichloromethane $(3 \times 10 \mathrm{~mL})$. The solvent was removed in vacuo to give the title compound 16 as a yellow oily solid (358 mg, 98\%). HRMS $\mathrm{m} / \mathrm{z}\left(\mathrm{ESI}{ }^{+}\right.$) calcd. for $\mathrm{C}_{11} \mathrm{H}_{21} \mathrm{~N}_{2} \mathrm{O}_{3}[\mathrm{M}+\mathrm{H}]^{+}$requires 229.1547 , found 229.1545, calcd. for $\mathrm{C}_{11} \mathrm{H}_{20} \mathrm{~N}_{2} \mathrm{NaO}_{3}[\mathrm{M}+\mathrm{Na}]^{+}$requires 251.1366, found 251.1365; $\mathbf{v}_{\max }(\mathrm{ATR}) / \mathrm{cm}^{-1} 3290$, 2932, 1656, 1531, 1130, 999; ${ }^{1} \mathrm{H}$ NMR $\left(400 \mathrm{MHz}, \mathrm{CDCl}_{3}\right) \delta 6.71(1 \mathrm{H}, \mathrm{d}, J$ 8.4, NH), $4.86(1 \mathrm{H}, \mathrm{d}, J$ 6.9, $\mathrm{CH})$, $4.55(1 \mathrm{H}, \mathrm{d}, J$ J 6.9, CH), $4.14(1 \mathrm{H}, \mathrm{dsept}, J 8.4,6.5, \mathrm{CH}), 3.23(2 \mathrm{H}, \mathrm{br} \mathrm{s}, \mathrm{OH}$ and $\mathrm{NH}), 3.03-2.96(2 \mathrm{H}, \mathrm{m}$, $\left.\mathrm{CH}_{2}\right), 2.89-2.79\left(2 \mathrm{H}, \mathrm{m}, \mathrm{CH}_{2}\right), 2.11-2.05\left(1 \mathrm{H}, \mathrm{m}, \mathrm{CH}_{2}\right), 1.94-1.70\left(3 \mathrm{H}, \mathrm{m}, \mathrm{CH}_{2}\right), 1.21\left(3 \mathrm{H}, \mathrm{d}, J 6.5, \mathrm{CH}_{3}\right)$, $1.17\left(3 \mathrm{H}, \mathrm{d}, \mathrm{J} 6.5, \mathrm{CH}_{3}\right) ;{ }^{13} \mathrm{C}$ NMR $\left(100 \mathrm{MHz} \mathrm{CDCl}_{3}\right)$ 169.7, 89.0, 78.9, 71.7, 42.8, 42.6, 41.2, 37.9, 32.6, 23.0, 22.7.

\section{Author Contributions}

AN conceived the project, and with GCG, carried out all the synthesis and analysis of scaffold structures, overseen by CJM; CAP conducted the library syntheses overseen by DH and GJ. AN wrote the paper with contributions from CJM, GCG and DH.

\section{Acknowledgements}

The research leading to these results was done within the European Lead Factory and has received support from the Innovative Medicines Initiative Joint Undertaking under grant agreement $\mathrm{n}^{\circ} 115489$, resources of which are composed of financial contribution from the European Union's Seventh Framework Programme (FP7/2007-2013) and EFPIA companies' in-kind contribution 


\section{A. Supplementary Material}

Electronic Supplementary Information (ESI) available: experimental details for library generation, copies of ${ }^{1} \mathrm{H}$ and ${ }^{13} \mathrm{C}$ NMR spectra. See DOI: $x x x x x x x x$

\section{References}

1. Nadin, A.; Hattotuwagama, C.; Churcher, I. Angew. Chemie Int. Ed. 2012, 51, 1114-1122.

2. Wetzel, S.; Bon, R. S.; Kumar, K.; Waldmann, H. Angew. Chem. Int. Ed. 2011, 50, 10800-10826.

3. Karawajczyk, A.; Giordanetto, F.; Benningshof, J.; Hamza, D.; Kalliokoski, T.; Pouwer, K.; Morgentin, R.; Nelson, A.; Müller, G.; Piechot, A.; Tzalis, D. Drug Discov. Today 2015, 20, 13101316.

4. Wuitschik, G.; Carreira, E. M.; Wagner, B.; Fischer, H.; Parrilla, I.; Schuler, F.; Rogers-Evans, M.; Müller, K. J. Med. Chem. 2010, 53, 3227-3246.

5. Burkhard, J. A.; Wuitschik, G.; Rogers-Evans, M.; Müller, K.; Carreira, E. M. Angew. Chemie Int. Ed. 2010, 49, 9052-9067.

6. Bull, J. A.; Croft, R. A.; Davis, O. A.; Doran, R.; Morgan, K. F. Chem. Rev. 2016, 116, 12150-12233.

7. Burkhard, J. A.; Guérot, C.; Knust, H.; Carreira, E. M. Org. Lett. 2012, 14, 66-69.

8. Wuitschik, G.; Rogers-Evans, M.; Buckl, A.; Bernasconi, M.; Märki, M.; Godel, T.; Fischer, H.; Wagner, B.; Parrilla, I.; Schuler, F.; Schneider, J.; Alker, A.; Schweizer, W. B.; Müller, K.; Carreira, E. M. Angew. Chemie Int. Ed. 2008, 47, 4512-4515.

9. Chalyk, B. A.; Isakov, A. A.; Butko, M. V; Hrebeniuk, K. V; Savych, O. V; Kucher, O. V; Gavrilenko, K. S.; Druzhenko, T. V; Yarmolchuk, V. S.; Zozulya, S.; Mykhailiuk, P. K. Eur. J. Org. Chem. 2017, 45304542.

10. Nicolle, S. M.; Nortcliffe, A.; Bartrum, H. E.; Lewis, W.; Hayes, C. J.; Moody, C. J. Chem. Eur. J. 2017, 
$13623-13627$.

11. Carreira, E. M.; Fessard, T. C. Chem. Rev. 2014, 114, 8257-8322.

12. Rosowsky, A.; Tarbell, D. S. J. Org. Chem. 1961, 26, 2255-2260.

13. Searles, S.; Gortatowski, M. J. J. Am. Chem. Soc. 1953, 75, 3030-3031.

14. Bach, T. Synthesis 1998, 683-703.

15. Wishka, D. G.; Walker, D. P. Tetrahedron Lett. 2011, 52, 4713-4715.

16. Ye, L.; He, W.; Zhang, L. J. Am. Chem. Soc. 2010, 132, 8550-8551.

17. Nortcliffe, A.; Moody, C. J. Bioorganic Med. Chem. 2015, 23, 2730-2734.

18. Nortcliffe, A.; Milne, G. D. S.; Hamza, D.; Moody, C. J. Bioorganic Med. Chem. 2017, 25, 22182225.

19. Murray, A. T.; Packard, E.; Nortcliffe, A.; Lewis, W.; Hamza, D.; Jones, G.; Moody, C. J. Eur. J. Org. Chem. 2017, 138-148.

20. Compound $\mathbf{9}$ was unstable to silica gel chromatography.

21. Hoffman, R. V; Kim, H. O.; Wilson, A. L. J. Org. Chem. 1990, 55, 2820-2822.

22. Determined from unoptimised reduction, where $d r=1: 1$ by ${ }^{1} \mathrm{H}$ NMR spectroscopy.

23. Novak, A.; Humphreys, L. D.; Walker, M. D.; Woodward, S. Tetrahedron Lett. 2006, 47, 57675769.

24. Doveston, R.; Marsden, S.; Nelson, A. Drug Discov. Today 2014, 19, 813-819.

25. Colomer, I.; Empson, C. J.; Craven, P.; Owen, Z.; Doveston, R. G.; Churcher, I.; Marsden, S. P.; Nelson, A. Chem. Commun. 2016, 52, 7209-7212. 